\title{
THE FUTURE OF MANKIND
}

New York, N. Y. Sir: The critical review and warm appreciation of Karl Jaspers' The Future of Mankind was most welcome. (Worldview, May, 1961) A "prolegomenon to. survival," as Father Murchland termed the book, seems to be as much as we can hope for at this time, but that in itself is a great deal, and we should place a high value on a work which lives up to that promise. Judging from the review, however, the promise seems unfulfilled and the reviewer's appreciation proportionately excessive. Although we are warned that the book is not to be regarded as a political tract, we are also told that it is at least partly that. My resexvations are directed particularly to that part, because, insofar as it is a political tract, it seems to be weak precisely where it should be most strong, as a work of reason assessing the modern predicament.

We are told that Jaspers reduces his discussion to an extreme thesis; "either mankind will physically perish or there will be a change in the moral-political condition of mankind." Later we are told that Jaspers' philosophy of transcendence allows hin to hold forth the hope of overcoming the present predicament, i.e., of achieving the second alternative, "however vague the specifics of realizing such a hope may be." And one of the great values of this, according to the reviewer, is that it is "already sufficient to set man on the way to a more intelligent manner of coping with his problems."

Two points of criticism are in order here, I think. First, the extreme thesis from which Jaspers argues is not immediately apparent, nor does it seem to be substantiated. We have not changed the moral-political situation of mankind since the development of nuclear weapons, no such change seems imminent, and yet to say that the destruction of mankind is approaching inevitably and inexorably unless the change takes place seems to many of us unduly pessimistic. Second, without accepting either Jaspers' extreme thesis or his philosophy of transcendence many of us hope and believe that the present situation can be overcome and, in that belief, are searching for the specifics.

It is comforting and reasurring to learn that a person of Jaspers' acknowledged philosophical stature can share the hope for a renewed future, for a transformation of our present predicament. And his reliance on and his asserion of the power of reason provide a needed and bracing tonic for our times.
While we can, therefore, welcome Jaspers' study we are most grateful for the thoughtful presentation of those views with which he has already made us familiar. Insofar as it is intended as a guide for the future of mankind, some reservations seem in order. This seems to be one of those books for which we can honestly raisc two cheers, but any more would be excessive.

JOHN WEBSTER.

\section{"FAREWELL MAGiC; FAREWELL MYTH"}

Crete, Nebraska Sir: In the editorial of the May issue you make a plea for realism. Such a plea comes with great fitness and it is made in fine style. However, the heading you use ("Farewell Magic; Farewell Myth") expresses a depth of disillusionment not quite in line with your plea for realism. You lament the President's blunder and then you go on to say that the lessons learned from it "may have been indispensible for the survival of us all." In that case the President's blunder is not so bad after all. Perhaps Mr. Kennedy deserves some credit for his own kind of realism. It is significant that he takes the blame for this supposed blunder.

We need to recall that the new Republican Senator from Texas has called for an invasion of Cuba. The Republican Senator from Arizona supports him. Our former Vice President has made similar pleas. Perhaps our new President's so-called blunder may prove to be an effective control of that part of our public which is eagerly willing to follow the Texas Republican. Our President's power to lead was sharply reduced when, last November, the hillbilly vote began to roll in from the American countryside. The temper of hillbilly feuds is notorious and $I$ am guardedly happy that a so-called hopeless blunder may have the promise of doing some good in preventing an even more hopeless blunder.

The political wisdom you call for is desperately needed. This is the wisdom which not only knows what can be done but is equally aware of what cannot be done. I recall the great half-truth expressed by the late Dr. Robert E. Park of the University of Chicago when he insisted that only those things ought to be done which can be done. This is a realism which may well alarm all liberals and comfort all conservatives. Whatever loss of prestige we may have suffered abroad we have gained something important at home.

JACOB F. BALZER 